\title{
Kadınların Çalışmasına Karşı Tutum ve Dini Yönelim Arasındaki İlişki
}

\begin{abstract}
Yıldız KUZGUN*
Seher A.SEVİM ${ }^{* *}$

ÖZ: Kadınların çalışmasına ilişkin yapılmış araştırmaların çoğu, çalışan kadınların ev ve işyerinde yaşadıkları zorlukları saptamaya yöneliktir. Bu araştırmada ise kadının çalışmasına karşı tutumlarla dini yönelim arasındaki ilişki incelenmiştir. Araştırmaya katılan bireylere Kuzgun tarafından geliştirilmiş Kadının Çalışmasına Karşı Tutum Ölçeği (KÇKTÖ) ile Onay (1997) tarafından geliştirilmiş Dini Yönelim Envanteri (DYE) uygulanmıştır. Verilerin analizinde Pearson korelasyon katsayısı ile iki faktörlü varyans analizi yöntemi kullanılmıştır. Araştırmaya katılan bireylerin KÇKTÖ ve DYE puanları arasındaki korelasyon katsayısı -0.35 olarak bulunmuştur. Yani, dini yönelim düzeyi ile kadının çalışmasına karşı olumlu tutum arasında ters yönde ve zayıf bir ilişki söz konusudur. Öte yandan, araştırmanın sonuçlarına dayanarak, eğitim düzeyi yükseldikçe kadının çalışmasına karşı olumlu tutumların arttığını ve dini yönelim düzeyinin azaldığını söylemek mümkündür.

Anahtar Sözcükler: Kadının çalışması, dini yönelim.

\section{The relationship between attitudes towards women's work roles and religious tendency}

ABSTRACT: Most of the studies done related to women's working aimed to reveal the difficulties that working-women experience at home and workplace. This research examined the relationship between attitudes toward women's working and religious tendency. Attitude towards Woman's Working Scale (ATWWS) developed by Kuzgun and Religious Tendency Inventory (RTI) developed by Onay (1997) were applied to the participants. Pearson correlation coefficient and two-way variance analysis method were used in the process of data analysis. Correlation coefficient between the participants' ATWWS and RTI scores was found as -0.35 , which means there is an negative and weak relationship between the two variables. On the other hand, based on the results of the research, it is possible to say that as the level of education rises, positive attitudes towards women's working increase and level of religious tendency decreases.
\end{abstract}

Key Words: Women's working, religious tendency

\section{GíRis}

Kadının toplumdaki yeri asırlardır ev ile sınırlandırılmış, işlevi ev işi ve çocuk yetiştirme olarak belirlenmiştir. On dokuzuncu yüzyıldan itibaren hızla gelişen endüstrileşme, geleneksel tarım toplumlarında ailenin ücretsiz işçisi olarak ağır iş yükü

\footnotetext{
* Prof. Dr., Ankara Üniversitesi Eğitim Bilimleri Fakültesi Emekli Öğretim Üyesi

** Yard. Doç. Dr., Ankara Üniversitesi Eğitim Bilimleri Fakültesi Öğretim Üyesi
} 
taşıyan kadına, eğitim görme ve ev dışında ücretli çalışma olanakları sağlamıştır. Eğitim düzeyinin yükselmesi ve toplumdaki işlevinin çeşitlenmesi ile kadın sosyal haklarını genişletmek için mücadeleye başlamıştır.

Cumhuriyetin ilanından sonra gerçekleştirilen devrimler çerçevesinde Türk kadınına önemli toplumsal haklar verilmiştir. Seçme seçilme hakk1, yasa önünde erkekle eşit konumda olma gibi temel haklar yanında 1936 İş Kanunu ile çalışma hayatında da bazı düzenlemeler yapılmıştır. Türkiye'de 1950 yılından itibaren sanayileşme süreci geliştikçe çalışan kadınların oranı da artmıştır (Kırkpınar, 1998). Kadınların eğitimi ve çalışmasıyla ilgili son yıllarda olumlu gelişmeler gözlenmesine rağmen, bu gelişme istenen düzeyde değildir. Belli mesleklerde çalışan kadın sayısı (özellikle yöneticilik) hala düşüktür ve kadınlar genellikle düşük gelirli, yükselme şansı sınırlı olan ve ev kadınlığı ile uyuşabilen geleneksel mesleklerde çalışmayı tercih etmektedirler (Kuzgun, 2000). Türkiye'de kadın işgücü açısından en büyük gelişme kamu hizmet sektöründe alt ve orta kademelerde olması bunu doğrulamıştır. 1938'de 12.716 olan kadın memur sayısı 1978'de 277.622'ye yükselmiştir. Türk toplumunda kadınların iş hayatı açısından hala istenilen düzeye ulaşamamış olmasındaki önemli etkenlerden birisi, yapılan tüm reformlara karşın toplumun geleneklerin baskısından kurtulamamış olmasıdır (Kırkpınar, 1998). Toplumumuzda egemen olan anlayışa göre, kadının yeri evidir ve asli görevi ev işi yaparak kocasına ve çocuklarına bakmaktır. Bu yüzden kadının "dışarıda çalışması" asli görevlerine aykırıdır. Kadının ev dışında ücretli olarak çalışması geleneksel ailelerde söz konusu değilken, 1950'lerden bu yana gelişen endüstrileşme ve bunun sonucu kentleşmenin gerektirdiği yaşam düzeyi sadece erkeğin kazancı ile karşılanamayacak derecede yükselmektedir. Bu durum kadının da gelir getirici bir işte çalışmasını zorunlu kılmaktadır (Ansal, 1996). Alt sosyo-ekonomik toplum kesiminde kadınların çalışmasını sadece ekonomik gerekçelerle açıklayan anlayışın son yıllarda değiştiğine ilişkin araştırma sonuçları da bulunmaktadır. Eraydın ve Erendil'in (1999) yaptığı araştırmanın sonuçlarına göre, konfeksiyon sektöründe çalışan kadınların \% 19.9'u geçim zorlukları nedeniyle, \% 46.9'u ise becerilerini kullanmak için çalışmaya başladıklarını ifade etmişlerdir.

Toplumun geniş kesiminde kadın işgücüne yönelik geleneksel bakış tarzının hala sürdüğü gözlenmektedir. Toplumun ve kadının kendisine biçtiği öncelikli rol "eş ve anne" ve bunun doğal sonucu olarak "ev kadını" olduğu sürece, kadın işgücünün "ucuz emek", "yardımcı aile işçisi" ve benzeri şekillerde tanımlanması kaçınılmaz olmaktadır (Minibaş, 1998). Kadınların esas istihdam biçimi de bu tanımlarla uyumlu bir şekilde ücretsiz aile işçisi olarak çalışmak olmaktadır. Kadınların üçte ikisinin bulabildiği olanak budur. Bunun anlamı, bir iş akdine göre belirlenmiş hakları olmaksızın ve herhangi bir sosyal sigortalar kurumuna kayıtlı olmadan çalışmalarıdır. Yani, istihdam olanağ bulan kadınların sadece \% 28'i sosyal sigorta kapsamına dahil olabilecek bir işte çalışmaktadır (Arın ve Ergin, 1998). Bu durumda toplumda kadının yerinin ev olduğu, eğitim görmüş kadınların bile güvenceyi evlilik ve ev kadını olarak yaşamakta gördükleri söylenebilir. 
Türkiye'de tarım kesimi dışında ücretli olarak ev dışında çalışan kadın sayısı çok azdır ve çalışan kadınlar da geleneksel rollerini sürdürebilecekleri, aile sorumluluklarıyla bağdaşabilen meslekleri yeğlemektedirler. Balkır'ın (1989) kadının kendini algılaması ile ilgili yaptığı bir çalışmada, "başarılı kadın" deyince iyi eş ve iyi anne akla geldiği belirlenmiştir. Erkeklere göre de başarılı kadın olabilmek için önce ev işlerinin aksatılmaması gerekmektedir. Kadınlar iyi eş, iyi ev kadını ve iyi anne gibi geleneksel rol beklentileriyle toplumsallaştırılmaktadır.

Geleneksel cinsiyet rolleri aile, akranlar, okul ve kitle iletişimi yoluyla öğrenilir. Hemen hemen her kültürde kız ve erkek çocuklara erken yaşlardan itibaren farklı davranılmaktadır. Sosyalleşme süreci boyunca kız çocukların uysal, yumuşak ve özverili; erkek çocukların ise yarışmacı, atak ve girişken olma davranışları pekiştirilmektedir. Muhtemelen bu eğitim fark1, kız ve erkek çocukların yöneldikleri serbest etkinlik türlerini ve dolayısıyla gizil güçlerini geliştirebilecekleri alanları, daha da ileride meslek seçimini ve meslek yaşamlarını etkilemektedir. Özellikle okullarda cinsiyet rollerine ilişkin kalıp yargılar açık ya da örtülü iletilerle çocuğa aktarılır. Bu iletiler yoluyla çocuklar geleneksel cinsiyet rollerine uygun davranışlara yöneltilirken, kadına ve erkeğe uygun başarı ölçütlerini ve sınırlarını da tanımlamaktadır (Tan, 2000). Ayrıca, okullarda okutulan ders kitapları yoluyla da kadınlara ilişkin toplumsal kalıp yargıları gelecek kuşaklara aktarılmaktadır (Dökmen, 1995, Helvacioğlu, 1996 ve Esen ve Bağl1, 2003). Yakın zamanda yapılan bir çalışmada bu görüşü doğrulayan bulular elde edilmiştir. Buna göre, İlköğretim 1.sınıf Abece ve Türkçe kitaplarında kadın figürler daha çok ev ve çevresinde, erkek figürler ise dış mekanlarda gösterilmektedir. Ayrıca, kadın figürler çocuğa yönelik, erkek figürler ise kamu ve iş yaşamıyla ilgili etkinlikler içinde resmedilmektedir (Esen ve Bağl1, 2003).

Kadınların meslek ve yaşam rollerinin zaman içerisinde değişip değişmediğini inceleyen bir araştırmada (Fiorentine, 1988), yeni kuşağın mesleki değerlerinin anlamlı ve olumlu yönde değiştiği, ancak ev içi rollerin değişmediği belirlenmiştir. Araştırmacıya göre, mesleklere yüklenen değerin artması kadınların meslek-ev ikileminde yaşadıkları çatışmayı arttırmaktadır. Bu görüş yapılan birçok araştırmanın verileriyle doğrulanmaktadır (Field ve Bramwell, 1998; Linda, 1995; Light, 1994). Japonya'da kadınların 30-34 yaşları arasında erken emekliliğe ayrılmasında en önemli nedenler doğum ve çocuk bakımıdır. Ev işleri ve çocuk bakımı kadının birincil görevleri arasındadır (Takahaski, 1994). Adler ve Brayfield (1997) tarafından yapılan Doğu Alman kadınları ile Batı Alman kadınlarının iş değerlerini karşılaştıran bir çalışmada ise Batı Alman kadınlarının iş değerlerinin çocuklarının varlığından daha çok etkilendiği ve geleneksel cinsiyet rolleriyle tutarlı olduğu bulunmuştur. Eyüboğlu ve ark. (2000) tarafından yapılan bir çalışmada da, Türkiye'de kadınların çalışma hayatından uzak durmalarının ardında yatan temel nedenlerin çocuk bakımının aksaması, ev düzeninin bozulması ve işyerinde yabancı erkeklerle bir arada olmanın olumsuz algılanması olduğu belirlenmiştir. 
Türkiye'de de kadınların çalışmasına ilişkin yapılmış çalışmaların çoğu, çalışan kadınların ev ve iş yerinde yaşadıkları zorlukları saptamaya yöneliktir. Çalışan 38 kadınla ayrıntılı görüşmeler yoluyla yapılan bir araştırmada (Ansal, 1996), kadınların çoğu (27 kadın) maddi zorunluluk olmasa çalışmaktan vazgeçebileceklerini, evdeki yüklerinin işyerinde sorumluluk alma ve yükselme konusunda isteksiz olmalarına neden olduğunu ifade etmişlerdir. Üst düzey yönetici olarak çalışan kadınlar ise iş hayatında ilerlemeyi istediklerini, ancak sorumluluklarının artmasıyla birlikte ev işlerinin aksadığını ve kocalarının bundan rahatsız olduğunu dile getirmişlerdir. Kadınlar bu nedenle çok sık bir şekilde, evlilikleri ile meslekleri arasında tercih yapma durumunda kalmaktadırlar. Nazlı (1997) tarafından yapılan bir araştırmada ise, profesyonel meslek sahibi kadınlarla alt düzeyde eğitim almış, "masa başı iş" denilen belli bir görevi ücret karşılığı belli saatlerde yerine getiren kadınlar çeşitli açılardan karşılaştırılmıştır. Her iki gruptaki kadınlar çocuk bakımı ve anneliğin kendileri için önemli olduğunu ve çocuk bakımı ile ilgili tüm sorumlulukların kendilerin ait olduğunu belirtmişlerdir. Aynı tür bir tutum eve ait işlerin paylaşımında da geçerlidir. "Kadın iş̧i, erkek işiı" ayrımını kabul etmemelerine rağmen, her iki gruptaki kadınların çoğunluğunun ev işlerinin hepsini üstlendiği görülmektedir. Profesyonel meslek sahibi kadınlar ise iş veya ev kadınlığının her ikisinin de önemli olduğunu ve her iki alandan yalnızca birisinde başarılı olmanın kendilerini mutsuz edeceğini belirtmişlerdir. Bu nedenle rol çatışmasını daha yoğun yaşamaktadırlar. Benzer bulgular Cindoğlu ve Muradoğlu'nun (1996) yaptığı araştırmada da elde edilmiştir. Bu çalışmada bilim kadınları eşlerinin kendilerine yardımcı olmaya istekli olduklarını ancak ev ile ilgili işlere çok az zaman harcadıklarını ifade etmektedirler. Kadın akademisyenler ev işleri ile baş etmede aile desteğini ve ücretli kadın emeğini kullanmaktadırlar. Evdeki iş yükünün tamamen kadınının üzerinde olması kadının çalışma ve mesleğinde ilerleme isteğini olumsuz etkilemektedir. Sonuçta, toplumda hala geçerliğini sürdüren "kadının yerinin evi olduğu" değer yargısının kadının iş hayatına girmesini ve mesleğinde ilerlemesini olumsuz etkilediğini söylemek mümkündür (Kazgan, 1979).

Türkiye'de kadınların çalışmasına karşı tutumları konu edinen araştırmalarda elde edilen bulgulara göz atıldığında genellikle kadının çalışmasına olumlu yaklaşıldığ 1 görülmektedir. Bununla birlikte, hala önemli sayıda kadının çalışmasının eşi, babası, kardeşi gibi diğer aile üyelerince engellendiği de üzerinde önemle durulması gereken bir gerçektir. Bir araştırmada Manisa ilinde yaşayan köylü grubun \%58'inin, işçilerin \%48'inin ve kentli grubun \%69'unun kadının ücretli bir işte çalışmasına karşı tutumlarının olumlu olduğunu saptanmıştır (Başaran, 1985). Kentlerde yaşayan kadınların çalışma hayatına katılmasını inceleyen bir araştırmada eşlerinin çalışmasını olumlu karşılayan erkeklerin oranının \% 54.40, buna karşı olanların oranının ise \% 44.68 olduğu; ancak, kadının çalışmasını engelleyen en önemli faktörün de eşin izin vermemesi ve çocukların bakımı olduğu belirlenmiştir (Tor, 1997). İstanbul'da Ümraniyeli kadınlarla yapılan bir çalışmada, kadınların çoğunluğunun (\% 52,8) ev dışında çalışmasının bunu uygun bulmayan diğer aile bireylerince engellendiği tespit edilmiştir (İlkkaracan, 1998). İstanbul, Ankara, İzmir ve Adana'da yaşayan 1125 kadınla yapılan araştırmanın sonuçlarına göre; araştırmaya katılan kadınların \% 95'i kadınların çalışma yaşamına 
katılması gerektiğine inanmakta, ancak grubun \% 74’ü koca veya babalarının kendilerinin çalışmasına gönüllü olmayacaklarını da belirtmektedirler (Eyüboğlu ve ark. 2000). Konfeksiyon sektöründe çalışan kadınlarla yapılan bir çalışmada ise evli kadınların kocalarının \% 34.9'u eşlerinin çalışmasına olumlu bakmaktadırlar. Bekar kızların ailelerinin ise \% 83.7'si kızlarının çalışmasını uygun bulmakta ve desteklemektedirler (Eraydın ve Erendil, 1999). Ergüder ve ark. (1991) tarafindan yapılan çalışmanın sonuçlarına göre ise araştırma grubunun \% 80'i ev kadını olmanın dışarıda çalışmak kadar tatmin sağlayacağına inanmasına rağmen, ailede her iki eşin çalışmasını grubun \% 86'sı kabullenmektedir. Sınırlı sayıda iş söz konusu olduğunda ise erkek adaylara öncelik verilmesine inananların oranı \% 52'dir. Ayrımcı değerler varlığını sürdürmesine rağmen kadınların ev dışında çalışmaları da kabul görmektedir, özellikle kadınların eğitim düzeyi yükseldikçe kadının çalışmasına yönelik olumlu değerlendirmeleri artmaktadır.

Ülkemizde kadının çalışmasına etki eden faktörleri inceleyen çalışmalar gözden geçirildiğinde; eğitim eksikliği, kocanın yaklaşımı, çocuk bakımı ve ev işlerinin önemli olduğu gözlenmektedir. Demirel ve ark. (1999) yaptıkları araştırma sonucunda kadın işsizliğinin altında yatan nedenleri olgusal ve yargısal olarak gruplamışlardır. Olgusal nedenler altında ülkedeki işsizlik oranının yüksekliği, kadınların aldığı ücretlerin düşüklüğü, kadınların eğitim ve beceri eksikliği, kreş ve yuvaların yeterince yaygın olmayışı gösterilirken; yargısal nedenler olarak kadının, kendini ve erkeği aile içinde ve annelik/babalıkla tanımlaması, bu rol içinde çalışmayı ve ev dışındaki hayatı erkeğe ait bir alan olarak görmesi, kendi alanını ev içi olarak tanımlaması bu değerler sisteminin yapı taşlarını oluşturmaktadır.

Kadının çalışmasına ilişkin toplumsal değer yargıları yanında; din de toplumumuzda geleneksel kural ve uygulamaları, bireyleri etkileyen bir üst yapı kurumudur. Din, geçmiş ve günümüz toplumlarında önemli bir unsur olarak karşımıza çıkar. Bireyin bir dini, herhangi bir derecede benimseme veya benimsememe şeklindeki değerlendirmesinin ifadesi Onay (2002) tarafından "Dini Yönelim" olarak tanımlanmıştır.Yani dini yönelim, insanın dinle ilgili psikolojik yönelimi, onun inanç dünyasıdır. Bireyin dinle ilgili değerlendirme ifade eden her çeşit tepkileri ve bunların derecesi kişinin dini yöneliminin göstergesidir. Dini yönelim dinlerdeki Tanrı ve ahret anlayışı ile birlikte ele alındığında üç önemli faktör öne çıkmaktadır: a) Dini düşünce ve inanç, b) Dini davranışlar-ibadet c) İlk iki faktörle ilişkili olarak kişinin duyguları ve ileriye yönelik karşılık beklentisi. Aslında kişinin dini yönelimi, yani dindarlığı bu temel faktörler üzerine kuruludur. Araştırmada kullanılan ölçme aracı yukarıda açıklanan dini yönelim anlayışına dayalı olarak geliştirilmiştir ve bu araştırmada "dini yönelimle kadınların çalışmasına yönelik tutumlar arasında bir ilişki var mıdır" sorusuna yanıt aranmıştır. Kadının çalışması hem kendi bireysel gelişimini, hem ekonomik bağımsızlığını, hem de ülke ekonomisini olumlu yönde etkileyeceği için kadının çalışmasını etkileyebilecek değişkenlerin belirlenmesi önem kazanmaktadır. 


\section{YÖNTEM}

Bu araştırma kadının çalışmasına karşı tutumlarla dini yönelim arasındaki ilişkiyi inceleyen bir durum saptama çalışmasıdır.

\section{Araştırma grubu}

Araştırma, 67'si kadın, 37'si erkek olmak üzere yetişkin 104 kişi üzerinde yapılmış bir araştırmadır. Bireylerin 11'i ilköğretim düzeyinde, 39'u lise, 54'ü ise üniversite ve lisans üstü düzeyde eğitim görmüştür. Grubun yaş ortalaması 32.21'dir.

\section{Ölçme araçları:}

$\mathrm{Bu}$ araştırmada, bireylerin kadınların çalışmasına yönelik tutumlarını belirlemek amacıyla, Kuzgun tarafından kadınların çalışmasına karşı tutumla ilgili olduğu düşünülen 27 maddelik bir ölçek hazırlanmıştır. Ölçek maddeleri ilgili literatür taranarak yazılmıştır ve ölçme değerlendirme ile sosyal psikoloji alanında çalışan uzmanların görüşleri alınarak ölçeğe son hali verilmiştir. Ölçeğin deneme uygulaması Eğitim Bilimleri Fakültesinde okuyan 112 son sınıf öğrencisinin anne ve babaları üzerinde yapılmıştır.

Ölçeğin yapı geçerliği faktör analizi yapılarak belirlenmiştir. İlk analizde maddelerin 5 boyutta dağıldığı görülmüştür. Birkaç kez yapılan istatistiksel analizler sonucunda faktör yükleri 0.40 'ın altında olan 12 madde çıkarılmıştır Kalan 15 maddenin faktör analizi sonuçları ve madde toplam korelasyonları Tablo 1'de gösterilmektedir.

Tablo 1. Kadının Çalışmasına Karşı Tutum Ölçeğinin Faktör Analizi Sonuçları ve

\begin{tabular}{cccc}
\multicolumn{4}{c}{ Madde Toplam Korelasyonlarl } \\
\hline Madde no. & $\begin{array}{c}\text { 1. Faktör } \\
\text { Yük Değeri }\end{array}$ & $\begin{array}{c}\text { Ortak } \\
\text { Varyans }\end{array}$ & Madde-Toplam r \\
\hline 01 & .76443 & .58436 & .7274 \\
02 & .60654 & .36789 & .5428 \\
03 & .69674 & .48545 & .6359 \\
04 & .68283 & .46626 & .6358 \\
05 & .76177 & .58029 & .7194 \\
06 & .69220 & .47914 & .6465 \\
07 & .62010 & .38453 & .5622 \\
08 & .76693 & .58819 & .7305 \\
09 & .71173 & .50656 & .6828 \\
10 & .73785 & .54442 & .6905 \\
11 & .77049 & .59366 & .7296 \\
12 & .70381 & .49535 & .6594 \\
13 & .76604 & .58681 & .7240 \\
14. & .57870 & .33489 & .4923 \\
15. & .59271 & .35130 & .5180 \\
\hline
\end{tabular}


Ölçekteki 1.faktör toplam varyansın 44.1'ini açıklamaktadır . Tek boyutlu olarak son şeklini alan ölçeğin her bir maddesinin toplam puan ile korelasyonu 0.30 ' un üzerindedir. Buna göre ölçeğin tüm maddelerinin ayırt edici olduğu düşünülmektedir. Ölçeğin iç tutarlılık katsayısı alfa $=.9250$ olarak bulunmuştur. Elde edilen verilere göre ölçeğin geçerli ve güvenilir bir ölçme aracı olduğu sonucuna varılmıştır.

Araştırmada kullanılan diğer bir ölçme aracı Onay (1997) tarafindan geliştirilmiş olan Dini Yönelim Envanteri (DYE)'dir. DYE, kişilerin yaşamında dinin ne derecede yer aldığını belirlemeyi amaçlayan bir ölçme aracıdır. Psikolojinin konusu olan yönelim; düşünce, davranış ve duygu boyutlarından oluşmaktadır. DYE, kişileri düşünce, davranış ve duygularında dinin ne ölçüde yer ettiğini sayısal değerlerle belirlemeye olanak vermektedir. Dini yönelim; bireylerin dini inançlarının, bilgi ve kabullerinin kendi duygu, düşünce ve davranışları üzerindeki etki düzeyi olarak kabul edilmiştir. DYE 25 maddeden oluşan 4 dereceli likert tipi bir ölçektir ve yapı geçerliği faktör analizi ile belirlenmiştir. Faktör analizi sonucunda faktör yükü 0.40 'ın altında olan maddeler envanterden çıkarılmıştır. Envanterin son halinde yer alan 25 maddenin faktör yük değerleri .50'nin üzerindedir ve tek boyut ile açılanan varyans miktarı ise .53.1'dir. DYE'nin güvenirliği Cronbach Alfa iç tutarlılık katsayısı 9619 , yarılama yöntemiyle iki yarım testten elde edilen güvenirlik katsayısı .9571 bulunmuştur.

\section{İstatistiksel Analiz}

Araştırmaya katılan bireylerin Kadının Çalışmasına Karşı Tutum Ölçeği ile Dini Yönelim envanterinden aldıkları puanlar arasındaki korelasyon, Pearson momentler Çarpımı Korelasyon katsayısı formulüyle hesaplanmıştır. Ayrıca cinsiyet ve eğitim düzeyine göre ortalamalar arasında fark olup olmadığı iki faktörlü varyans analizi yöntemi ile incelenmiştir. İki faktörlü varyans analizi (ANOVA), gruplar arası iki faktörün bir bağımlı değişken üzerindeki etkisini ayrı ayrı test etmek yerine faktörlerin temel etkilerini ve iki faktörün bağımlı değişken üzerindeki ortak etkisini eş zamanlı olarak test etmektedir (Büyüköztürk, 2003).

\section{BULGULAR}

Araştırmaya katılan 104 bireyin eğitim düzeyleri ve cinsiyete göre dini yönelim ölçeği ve kadının çalışmasına yönelik tutum ölçeğinden aldıkları puanların ortalamaları ve standart sapmaları Tablo 2'de verilmiştir.

Değişik eğitim düzeylerindeki kadınların ve erkeklerin kadının çalışmasına yönelik tutum ölçeğinden aldıkları puanların ortalamalarına bakıldığında, eğitim düzeyi yükseldikçe ortalamaların yükseldiği görülmektedir.

Tablo 3 incelendiğinde, hem kadın hem de erkeklerin eğitim düzeyi yükseldikçe dini yönelim ölçeğinden aldıkları puanların ortalamalarının düştüğü söylenebilir.

Araştırmaya katılan bireylerin KÇKTÖ ve DYE puanları arasındaki korelasyon katsayısı -035 olarak bulunmuştur. İlişkinin yönü eksi, miktarı oldukça düşüktür. $\mathrm{Bu}$ bulgu kadının çalışmasına taraftar olmayanların bir kısmının dini yönelim düzeyi yüksek 
kişiler olduğunu ya da dini yönelim düzeyi düşük kimselerden bir kısmının kadının çalışmasına karşı olduklarını göstermektedir.

Tablo 2. KÇKTÖ Puanlarına İlişkin Ortalama ve Standart Sapmalar

\begin{tabular}{lllccc}
\hline & Okul & Cinsiyet & Ortalama & SS & N \\
\hline Kadının & \multirow{3}{*}{ İlöğretim } & Kadın & 50 & 9,75 & 8 \\
Çalışmasına & Erkek & 53,33 & 2,08 & 3 \\
Yönelik & & Toplam & 50,91 & 8,36 & 11 \\
Tutum & & Kadın & 61,09 & 8,78 & 23 \\
& \multirow{2}{*}{ Lise } & Erkek & 47,93 & 11,94 & 15 \\
& & Toplam & 55,89 & 11,93 & 38 \\
& \multirow{4}{*}{ Üniversite } & Kadın & 62,08 & 9,21 & 36 \\
& & Erkek & 59,32 & 6,51 & 19 \\
& Toplam & 61,13 & 8,42 & 55 \\
& Kadın & 60,3 & 9,78 & 67 \\
& \multirow{2}{*}{ Toplam } & Erkek & 54,22 & 10,35 & 37 \\
& & Toplam & 58,13 & 10,36 & 104 \\
\hline
\end{tabular}

Tablo 3. DYE Puanlarına İlişkin Ortalama ve Standart Sapmalar

\begin{tabular}{cccccc}
\hline & Okul & Cinsiyet & Ortalama & $\begin{array}{c}\text { Standart } \\
\text { Sapma }\end{array}$ & N \\
\hline Dini Yönelim & \multirow{6}{*}{ İlköğretim } & Kadın & 81,13 & 7,02 & 8 \\
& & Erkek & 75,67 & 14,47 & 3 \\
& Toplam & 79,64 & 9,1 & 11 \\
& Kadın & 58 & 15,61 & 23 \\
& \multirow{4}{*}{ Lise } & Erkek & 70 & 16,27 & 15 \\
& Toplam & 62,74 & 16,74 & 38 \\
& Kadın & 63,17 & 17,87 & 36 \\
\multirow{2}{*}{ Üniversite } & Erkek & 55,42 & 19,11 & 19 \\
& & Toplam & 60,49 & 18,51 & 55 \\
& Kadın & 63,54 & 17,44 & 67 \\
& \multirow{2}{*}{ Toplam } & Erkek & 62,97 & 19,01 & 37 \\
& Toplam & 63,34 & 17,92 & 104 \\
\hline
\end{tabular}

Cinsiyet ve eğitim düzeyine göre dini yönelim ve kadının çalışmasına karşı tutumlarının farklılaşıp farklılaşmadığı iki faktörlü varyans analizi ile incelenmiştir. Varyans analizi sonuçları Tablo 4 ve 5'de verilmiştir. 
Dini yönelim ve kadının çalışmasına karşı tutum puanlarında cinsiyet ve eğitim düzeyine göre fark olup olmadığı iki faktörlü varyans analizi ile incelenmiştir. Anlamlı etkilerin bulunduğu durumlarda gruplar arası farkl1liklar Tukey testi kullanılarak değerlendirilmiştir. Araştırmada anlamlılık düzeyi olarak .01 kabul edilmiştir.

Araştırmaya katılan bireylerin KÇKTÖ puanları arasında cinsiyete (cinsiyet temel etkisi) göre fark bulunmadığı, $(\mathrm{F}(2,98)=2.95 \mathrm{p}>.05$; $)$ ama eğitim düzeyine göre fark olduğu belirlenmiştir $(F(2,98)=6.84 p<.01$.) Ayrıca cinsiyet ve eğitim düzeyinin kadının çalışmasına karşı tutum üzerindeki ortak etkisinin de anlamlı olduğu gözlenmiştir ( $\mathrm{F}(2,98)=4.74 \mathrm{p}<.01$.) Farkların kaynağını belirlemek amacıyla yapılan Tukey testi sonuçlarına göre, ilköğretim düzeyinde eğitim görmüş kadınlarla üniversite düzeyinde eğitim görmüş kadınların, kadının çalışmasına yönelik tutumlarının anlamlı düzeyde farklı olduğu belirlenmiştir $(\mathrm{t}=3.32 \mathrm{p}<.01)$. Ayrıca, ilköğretim düzeyinde eğitim görmüş kadınlarla lise düzeyinde eğitim görmüş kadınların kadının çalışmasına yönelik tutumları da birbirinden farklıdır $(\mathrm{t}=2.9 \mathrm{p}<.01)$. Farklılık belirlenen diğer bir grup ise lise düzeyinde eğitim görmüş erkeklerle üniversite düzeyinde eğitim görmüş erkeklerin tutumları arasındadır. Ayrıca, kadınlarla erkekler arasında kadınların çalışmasına yönelik tutumların farklı olduğu tek grup ise lise düzeyindeki kadınlar ve erkeklerdir $(\mathrm{t}=3.91$ $\mathrm{p}<.01)$.

Tablo 4. Eğitim Düzeyi ve Cinsiyete Göre Kadının Çalışmasına Yönelik Tutum Puanlarına ilişskin F değerleri

\begin{tabular}{cccccc}
\hline Kaynak & $\begin{array}{c}\text { Kareler } \\
\text { Toplamı }\end{array}$ & $\begin{array}{c}\text { Kareler } \\
\text { Ortalaması }\end{array}$ & Sd & F & P \\
\hline Eğitim Düzeyi & 1130.858 & 565.429 & 2 & 6.841 & 0.002 \\
Cinsiyet & 244.193 & 244.193 & 1 & 2.954 & 0.089 \\
$\begin{array}{c}\text { Eğitim Düzeyi ve } \\
\text { Cinsiyet }\end{array}$ & 783.803 & 391.902 & 2 & 4.741 & 0.011 \\
Toplam & 11048.115 & - & - & - & -
\end{tabular}

Araştırmanın diğer bir değişkeni olan dini yönelim düzeyleri açısından grupları karşılaştırdığımızda, cinsiyete göre fark olmadığ $1(\mathrm{~F}(1,98)=0,008 \mathrm{p}>.01)$, ancak eğitim düzeyine göre fark olduğu $(\mathrm{F}(2,98)=4.95 \mathrm{p}<.01)$ cinsiyet ve eğitim düzeyinin dini yönelim üzerindeki ortak etkisinin ise anlamlı olmadığ gözlenmektedir $(F(2,98)=3.764$ $\mathrm{p}>$.01) . 
Tablo 5 - Eğitim Düzeyi ve Cinsiyete Göre Dini Yönelim Puanlarına ilişkin F değerleri

\begin{tabular}{cccccc}
\hline Kaynak & $\begin{array}{c}\text { Kareler } \\
\text { Toplamı }\end{array}$ & Kareler Ortalaması & Sd & F & P \\
\hline Eğitim Düzeyi & 2786.258 & 1393.129 & 2 & 4.951 & 0.009 \\
Cinsiyet & 2.234 & 2.234 & 1 & 0.008 & 0.929 \\
Eğitim Düzeyi ve Cinsiyet & 2118.465 & 1059.232 & 2 & 3.764 & 0.027 \\
Toplam & 33077.221 & - & - & - & - \\
\hline
\end{tabular}

Eğitim düzeyine göre grupların ortalamalarına bakıldığında farkın ilköğretim düzeyindeki bireylerin oluşturduğu grup 1'den kaynaklandığı belirlenmiştir (Grup 1 (ilköğretim) $X=79,64$, grup 2 (lise) $X=62,74$, grup 3 (üniversite) $X=60,49$,). Yani ilköğretim düzeyindeki bireylerin dini yönelim puan ortalamaları hem lise hem üniversite düzeyindeki bireylerden daha yüksektir ve anlamlı olarak diğer iki gruptan farklıdır.

Araştırma grubundaki bireylerin dini yönelim ölçeğinden aldıkları puanların ortalamaları hesaplanmış ve ortalamanın 1ss üstündeki bireyler dini eğilimi yüksek bireyler, ortalamanın 1 ss altındaki bireyler ise dini eğilimi düşük bireyler olarak değerlendirilmiş ve bu iki farklı grubun kadınların çalışmasına yönelik maddelerde farklı olup olmadığ $1 \mathrm{t}$ testi ile incelenmiştir.

Tablo 6 - Kadının çalışmasını yönelik maddelerin ortalamaları ve t testi sonuçları

\begin{tabular}{|c|c|c|c|}
\hline & 1.grup X & 2.grup $X$ & $\mathbf{t}$ \\
\hline 1.İyi nesiller yetiştirebilmek için, kadının çocuğuna bakması gerekir. & 2.90 & 4.21 & $-3,493 *$ \\
\hline 2.Kadınlar iş hayatındaki engeller ve güçlüklerle baş edebilirler. & 3.90 & 4.32 & $-1,636$ \\
\hline $\begin{array}{l}\text { 3.Kadınların çalışma hayatına girmesi, erkekler arasında işsizliğe yol açacağı } \\
\text { için sakıncalıdır. }\end{array}$ & 3.24 & 4.47 & $-3,319^{*}$ \\
\hline $\begin{array}{l}\text { 4.Kadınlar aylık rahatsızları ve doğum yapmaları nedeniyle iş hayatında } \\
\text { verimsiz olmaktadırlar. }\end{array}$ & 4.76 & 3.68 & ,722 \\
\hline $\begin{array}{l}\text { 5.Kadınlar iş hayatında cinselliklerini ön plana çıkararak, ayrıcalık sağlamaya } \\
\text { çalışmaktadırlar. }\end{array}$ & 3.33 & 3.58 & $-5,92$ \\
\hline 6.Çalışan kadının çocuğu sevgiden yoksun büyümektedir. & 2.38 & 3.53 & $-3,043 *$ \\
\hline $\begin{array}{l}\text { 7.Kocası eve bakabilecek ve ihtiyaçlarını karşılayabilecek durumda olsa bile, } \\
\text { kadının çalışması gerektiğine inanyorum. }\end{array}$ & 3.10 & 3.84 & $-1,973$ \\
\hline $\begin{array}{l}\text { 8. Kadınlarla erkeklerin birlikte çalıştığı iş ortamında erkekler tahrik olduğu } \\
\text { için verim düşebilir. }\end{array}$ & 3.62 & 4.32 & $-1,977$ \\
\hline $\begin{array}{l}\text { 9. Kadınlar ev işlerini aksatmayacak şekilde hafif veya yarım zamanlı işlerde } \\
\text { çalışmalılar. }\end{array}$ & 2.05 & 3.42 & $-3,876^{*}$ \\
\hline $\begin{array}{l}\text { 10.Kadınlar duygularına göre davrandıkları için işlerinde ortaya çıkan } \\
\text { sorunları çözemezler. }\end{array}$ & 3.52 & 4.21 & $-1,963$ \\
\hline $\begin{array}{l}\text { 11.Kadınlar daha bilgili ve görgülü olmak için yüksek öğrenim görmeliler, } \\
\text { ancak çalışmalarına gerek yoktur. }\end{array}$ & 3.43 & 4.11 & $-1,661$ \\
\hline 12.Kadınların çalıştığ iş ortamlarında gayrı meşru ilişkiler olabilir. & 3.19 & 3.58 &,- 905 \\
\hline $\begin{array}{l}\text { 13.Kadının birinci görevi, evin sorumluluğunu üstlenmek ve çocuk } \\
\text { yetiştirmektir. }\end{array}$ & 2.38 & 3.47 & $-2,709 *$ \\
\hline $\begin{array}{l}\text { 14.Kadına çalışma hakkı vermek, ona yeteneklerini geliştirme olanağ } 1 \text { vermek } \\
\text { demektir. }\end{array}$ & 3.62 & 4.26 & $-1,967$ \\
\hline 15.Kadın işgücünden yararlanmak toplum kalkınmasını hızlandırabilir. & 4.14 & 4.26 &,- 412 \\
\hline
\end{tabular}
*işaretli maddelerin ortalamaları .01 düzeyinde anlamlıdır. 
Tablo 6'da madde ortalamaları ve iki gruba ilişkin $\mathrm{t}$ testi sonuçları verilmiştir. Tabloda 1 numaralı grup dini eğilim puanları yüksek bireyleri, 2 numaralı grup ise dini eğilim puanları düşük bireyleri göstermektedir. İki grubun ortalamaları arasındaki farkın test edilmesi sonucunda 1,3,6,9,13 numaralı maddelerine ilişkin puan ortalamalarının farklı olduğu anlaşılmaktadır.

\section{TARTIŞMA}

Araştırmanın sonuçlarına göre, dini yönelim düzeyi ile kadının çalışmasına karşı olumlu tutum arasında ters yönde ama düşük bir ilişki bulunmuştur. Kadının çalışmasına karşı tutumları cinsiyet ve eğitim düzeyine göre incelediğimizde, sadece lise düzeyinde eğitim görmüş erkeklerle kadınlar arasında fark belirlenmiştir. Yani lise düzeyinde eğitim görmüş kadınların, kadının çalışmasına yönelik tutumları daha olumludur; Eğitim düzeyleri farklı kadınların kadının çalışmasına karşı tutumları karşılaştırıldığında üniversite düzeyinde eğitim görmüş kadınların, ilköğretim düzeyinde eğitim görmüş kadınlara göre, kadınların çalışmasına karşı tutumlarının daha olumlu olduğu görülmüştür.

Genel olarak kadınların eğitim düzeyi arttıkça kadının çalışmasına yönelik olumlu tutumlarının arttığı söylenebilir. Buna karşı1lık sadece üniversite eğitim almış erkekler kadının çalışmasını olumlu olarak değerlendirmektedirler eğitim düzeyi arttıkça kadının çalışmasına karşı olumlu tutumların artması tutumların gelişmesinde eğitimin rolünü ortaya koyan bir bulgu olarak kabul edilebilir. Eğitim düzeyinin yükselmesiyle kadının çalışmasına karşı olumlu tutumların artması Demirel ve ark. (2000) tarafından yapılan çalışmada da vurgulanmaktadır. $\mathrm{Bu}$ nedenle ülkemizde eğitime kadınların erkeklerle eşit oranlarda katılması, ilköğretimin zorunlu, kız çocukların ve kadınların laik ve çağdaş eğitimden pay almaları konusunda kampanyalar düzenlenmelidir. Tan'a göre (2000), daha çok kadının eğitime katılması veya uzun süre sistem içinde kalmaları eşitlik sağlamaya yetmez. Okul ya da eğitim sistemi toplumsal cinsiyete yönelik yeni ölçütlerin, rollerin, tutumların gelişmesi için ortam olarak kullanılmalıdır ve kadınların her düzeyde eğitim politikalarının belirlenmesine katılması sağlanmalıdır.

Araştırmaya katılan bireylerin dini yönelim düzeyleri cinsiyet ve eğitim düzeyi bakımından karşılaştırıldığında, eğitim düzeyi yükseldikçe dini yönelim düzeyinin düştüğü, cinsiyet bakımından ise sadece lise düzeyindeki kadın ve erkekler arasında fark olduğu belirlenmiştir. Voltan-Acar, Yıldırım ve Ergene (1996) tarafından yapılan çalışmada erkeklerin kadınlardan daha dindar olduğu, öğrenim düzeyi düştükçe çok dindar ve dindarların oranında bir artış olduğu; buna karş11ık öğrenim düzeyi yüksek gruplarda bu oranda azalma olduğu gözlenmiştir. Bu bulgu, araştırmada elde edilen sonuçlarla tutarlıdır.

Dini eğilimleri farklı iki grup (yüksek ve düşük puan alanlar) karşılaştırıldığında, iki grubun ortalamaları 1,3,6,9 ve 13 ncü maddelerde birbirinden farklıdır. Bu maddelerde dini eğilimi yüksek bireylerin ortalamaları düşüktür. İlgili maddeler gözden geçirildiğinde, üçüncü madde dışındakilerin kadının geleneksel rolleri olarak algılanan çocuk yetiştirme ve ev işleriyle ilgili olduğu görülmektedir. Dini yönelim düzeyi yüksek 
bireyler kadının birincil görevinin çocuk yetiştirme ve ev işi olduğunu; ev işlerini aksatmayacak şekilde çalışması gerektiğini ifade etmektedirler. Bu dört maddede, kadının geleneksel cinsiyet rolleriyle ilişkilidir ve kadından öncelikle bu görevlerini yerine getirmesi beklenmektedir. Bu da kadının ev işleri ile iş yaşamı arasında yoğun bir çatışma yaşamakta olduğunu göstermektedir. Bu bulgular, hem Türkiye'de hem de yurt dişında yapılmış araştırmaların bulgularıyla desteklenmektedir (Cindoğlu ve Muradoğlu, 1996; Nazlı, 1997; Field ve Bramwell, 1998). Becker-Schmidt'e (1996) göre de, kadının alanı hala ev işi ile sınırlandırılmakta ya da dışarıda çalışmaya tercih edilmesi gerektiğine inanılmaktadır. Kadınların bir meslekte çalışmaları erkeklerle aynı statüde değerlendirilmemektedir. Kadının çalışması, onun yaşamını kazanarak bağımsızlaşmasını sağlayan etkinlik olarak değil eve ek gelir sağlayan etkinlik olarak görülmektedir. $\mathrm{Bu}$ çalışmada da kadının çocuk bakması, ev işlerini yapması ve ev işlerini aksatmayacak şekilde çalışmasının vurgulandığı söylenebilir. Ancak, burada islamiyetin kadına bakış açısının bu olmadığı da vurgulanmalıdır. Öztürk'e (2000) göre "kadının evde oturmas1 gerektiğini iddia etmek" açıkça bir "gelenekçi saptırmadır".

$\mathrm{Bu}$ çalışmada kadının çalışmasına yönelik tutumlarla dini yönelim arasında bulunan ilişki yüksek değildir. Toplumda kadının çalışması ile ilgili tutumlar dini inançlarımızdan etkilendiği bir gerçektir ama kadının çalışmasına karşı tutumların tümünün dinden kaynaklandığını söylemek mümkün değildir. Bu çalışmada kadının çalışması üzerinde dini yönelimden daha çok geleneksel cinsiyet rollerinin etkili olduğunu gösteren bulgular elde edilmiştir. Özellikle dini eğilimi yüksek bireyler geleneksel cinsiyet rolleriyle ilgili maddelere daha çok katıldıklarını ifade etmişlerdir. Cinsiyet rollerinin belirlenmesinde ise toplumdaki değer yargılarının etkili olduğu bilinmektedir. Bireylerden görüşme yoluyla elde edilecek bilgilerle ve ayrıntılı incelemelerle bu gibi sorulara yanıt bulunabilir. Bu nedenle, kadının çalışması üzerinde cinsiyet rolleri ile dini kuralların etkisini inceleyen yeni araştırmalara gerek olduğu düşünülmektedir.

\section{KAYNAKÇA}

Acar, N., Yıldırım, İ. Ve Ergene, T. (1996). Bireylerin dindarlık düzeylerinin bazı değişkenler açısından incelenmesi. Hacettepe Üniversitesi, Eğitim Fakültesi Dergisi, 12. 45-46.

Adler, M. ve Brayfield, A. (1997). Women's work values in unified Germany. Work and Occupations, 24.(2),245-266.

Ansal, H. (1996). Teknolojik gelişmelerin sanayide kadın istihdamına etkileri: Türk tekstil ve elektronik sanayilerinde teknolojik değişim ve kadın istihdamı. Ankara: T.C. Başbakanlık Kadının Statüsü ve Sorunları Genel Müdürlüğü.

Arın, T. ve Ergin, B. (1998). Türkiye'de sosyal güvenlik ve kadınlar: Yasal çerçeve ve uygulama. N.Arat, (der.) Aydınlanmanın Kadınları içinde (s.235-238). İstanbul: Cumhuriyet Kitap Kulübü. 
Balkır, A. (1989). Kadınların Kendini Algılaması. Yayınlanmamış yüksek lisans tezi. A.Ü.Sosyal Bilimler Enstitüsü.

Becker-Schmidt, R. (1996). Sosyal bilimlerin kadın araştırmalarındaki teorik anlayış ve düşün-yöntemsel düşünceler. H.Coşkun (der.) Akademik Yaşamda Kadın içinde (s.389-395). Türk Alman kültür işleri kurulu yayın dizisi. Ankara: Bizim Büro Basımevi.

Büyüköztürk, Ş.(2003). Veri Analizi El Kitabı. 3.Baskı. Ankara: Pegem Yayıncılık.

Cindoğlu, D. ve Muradoğlu, G. (1996). Muhasebe ve finans dalındaki bilim kadınlarının iş ve aile rolleri ile başetme stratejileri. H.Coşkun. (der.) Akademik Yaşamda Kadın içinde (s.244-250). Türk Alman kültür işleri kurulu yayın dizisi. Ankara: Bizim Büro Basımevi.

Demirel, A., Kayaalp Bilgin, Z. Ve Kocaman, M. (1999). Çalışmaya Hazır İşgücü Olarak Kentli Kadın ve Değişimi. Başbakanlık Kadının Statüsü ve Sorunları Genel Müdürlüğü Yayınları. Ankara: Cem Web Ofset.

Dökmen, Z. (1995).İlkokul ders kitaplarının cinsiyet rolleri açısından incelenmesi. 3P, $3(2), 38-44$

Eraydın, A. ve Erendil, A. (1999). Yeni Üretim Süreçleri ve Kadın Emeği. Başbakanlık Kadının Statüsü ve Sorunları Genel Müdürlügü Yayınları. Ankara: Cem Web Ofset.

Ergüder, Ü., Esmer, İ. ve Kalaycığlu, E. (1991). Türk Toplumunun Değerleri. İstanbul: TÜSİAD Yayınları.

Esen, Y. ve Bağlı, M. (2003). İlköğretim ders kitaplarındaki kadın ve erkek resimlerine ilişkin bir inceleme. Ankara Üniversitesi Eğitim Bilimleri Fakültesi Dergisi, 35, (12), 143-154.

Eyüboğlu, A., Özar, Ş. ve Tanröver, H.T. (2000). Kentlerde Yaşayan Kadınların İş Yaşamına Katılım Sorunlarının Sosyoekonomik ve Kültürel Boyutları. Başbakanlık Kadının Statüsü ve Sorunları Genel Müdürlüğü Yayınları, Ankara: Cem Web Ofset.

Field, S. ve Bramwell, R. (1998). An investigation into the relationship between caring responsibilities and the levels of perceived pressure reported by female employees. Journal of Occupational and Organizational Psychology, 71(2), 165-169.

Fiorentine, R. (1988). Increasing similarity in the values and life plans of male and female college students. Evidence and implications. Sex Roles, 18 (3-4), 143-157.

Helvacıoğlu, F. (1996). Ders Kitaplarında Cinsiyetçilik. 1. Baskı. Ankara: Kaynak Yayınlar1.

İlkkaracan, İ. (1998). Kentli kadınlar ve çalışma yaşamı. A.B. Hacımirzaoğlu (der.). 75 Yılda Kadınlar ve Erkekler içinde (s.285-302). İstanbul: Tarih Vakfi Yayınları.

Kazgan, G. (1979). Türk ekonomisinde kadınların iş gücüne katılması, meslek dağılımı, eğitim düzeyi ve sosyo ekonomik statüsü. N.A. Unat (der.). Türk Toplumunda Kadın içinde. Ankara: Sosyal Bilimler Yayını.

Kırkpınar, L. (1998). Türkiye'de Toplumsal Değişme Sürecinde Kadın. A.B. Hacımirzaoğlu (der.). 75 Yılda Kadınlar ve Erkekler içinde (s.13-28). İstanbul: Tarih Vakfı Yayınları. 
Kuzgun, Y. (2000). Meslek Danışmanlı̆̆ı. Ankara: Nobel Yayın Dağıtım.

Light, H.K. (1994). Differences in employed women's anxiety, depression and hostility levels according to their career and family role commitment. Psychological Reports, 55, 290.

Linda, N. (1995). Indexes of psychological well-being and role commitment among working women. Journal of Employment Counseling, 32(1), 22-30.

Minibaş, T. (1998). Türkiye'nin kalkınma sürecinde kadın işgücü. N.Arat (der.). Aydınlanmanın Kadınları içinde(s. 331). İstanbul: Cumhuriyet Kitap Kulübü.

Nazlı, O.A. (1997). Çalışan evli kadınlarda aile ve çalışma yaşamına ilişkin rol çatışması. 20. Yüzyılın sonunda Kadınlar ve Gelecek Konferansı. 19-21 Kasım 1997. Poster bildiri. Türkiye ve Orta Doğu Amme İdaresi Enstitüsü.

Onay, A. (1997). Dini Yönelim Düzeyi ile sınav kaygısı ilişkisi ve sınav kaygısında hipnoterapi, yayınlanmamış yüksek lisans tezi. Ankara: A.Ü.İlahiyat Fakültesi.

Onay, A. (2002). Dini yönelim ölçeği. Íslamiyat Dergisi. 5 (4),181-192.

Öztürk, Y.N. (2000). İslam Nasıl Yozlaştırıldı? 1. Bask1. İstanbul: Yeni Boyut.

Takahaski, M. (1994). The issues of gender in contemporary Japanese working life: A Japanese "vicious circle". Feminist Issues, 14(1), 37-56.

Tan, M. (2000). Eğitimde kadın-erkek eşitliği ve Türkiye gerçeği. Kadın-Erkek Eşitliğine Doğru Yürüyüşs- Ĕgitim, Çalışma Yaşamı ve Siyaset içinde (s.23-114). Ankara: TÜSIAD Yayınları.

Tor, H. (1997). Kentsel kesimde yaşayan kadınların çalışma hayatına katılamamalarını etkileyen etmenler. 20. Yüzyılın sonunda Kadınlar ve Gelecek Konferansı. 19-21 Kasım 1997. Poster bildiri. Türkiye ve Orta Doğu Amme İdaresi Enstitüsü. 